\title{
JKMA Opinion
}

\section{급증하는 노이병원의 현황과 대채 The Current Status and Measures of Ever-increasing Geriatric Care Hospitals}

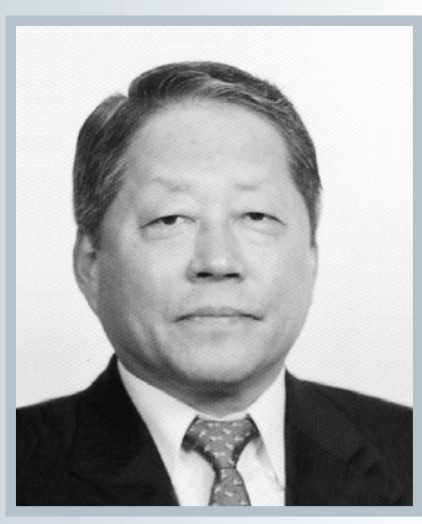

\section{신 양 식}

연세의대 마취통증의학과

\section{Yang-Sik Shin, MD}

Department of Anesthesiology and Pain Medicine, Yonsei University College of Medicine E-mail : ysshin@yumc.yonsei.ac.kr

J Korean Med Assoc 2006; 49(12): 1062 - 1066

\section{Abstract}

any health care hospitals for the elderly ("Geriatric care hospital") are being founded as a result the rapid increase in the
elderly population in Korea. As the population in Korea ages, there is move toward a mass geriatric society with a corresponding increase in the number of and geriatric care hospitals beds. Accordingly, the government's health care policy, social ethics and medical care services must change in order to adapt to the aging society. In general, when the cost and quality grows hand in hand and quality improvements are needed to meet expectations, unnecessary expenses can be reduced. The government can be expected to take on the role to firmly secure this balance. In addition, medical institutions must be aware that an investment based solely on profit can have deleterious outcomes. In conclusion, geriatric care hospital should not be evaluated only by its expansion in size or need, but should be judged on the consistent improvement in the quality of medical services they provide. The government, a group of hospital administrators or a social-welfare groups cannot solve this task alone. The government must offer legal, institutional and financial support, while people of all fields must find some common ground in geriatric care. Moreover, the development of an appropriate and efficient supervising system for geriatric care, and greater efforts of the geriatric hospitals themselves are needed to improve medical care. 
인구의 고령화로 인하여 노인 인구가 폭증하는 추세 를 보이고 있고 그에 따른 사회 문제가 각 분야에서 노 출되고 문제 해결을 위해 각계각층의 노력이 절실하다 는 주장이 일고 있다. 노인의 자살이 급증하는 것이 최 근 노인의 사회적 문제의 단면을 보여준다. 경찰청 통계 에 따르면 전국 노인(61세 이상) 자살자가 2000년에 2,329 명이던 것이 3 년 후 3,653 명으로, 하루 평균 10 명 의 노인이 자살하는 꼴이라고 한다.

사회적 측면에서 보는 노인이란 정의는 생물학적 또 는 의학적인 정의와는 달리 자연 나이만을 기준으로 하 지는 않는다. 물론 자연 노인의 기준 연령도 다양하며 65 세가 일반적으로 인정되는 숫자다. 생산성만을 고집 하는 사회로 변모하면서 자의든 타의든 이른 나이에 일 손을 놓고 삶의 가치 판단마저 흐려지는 효용 일변도사 회에서 '기능적 노인' 은 자연 노인의 증가와 더불어 인 구 비의 불균형에 일조를 하고 있다. 또한 후자의 경우 도 상당수가 자연 노인과 같은 복지 대상이요, 노인 의 료 대상으로 진입하는 결과를 초래하고 있다. 노인 인구 의 장래 추계를 보면, 2025 년까지 지속적으로 매년 $20 \%$ 내외의 노인 인구가 증가하며 노인 인구 비는 2000 년도에 $7.2 \%$ 이던 것이 꾸준히 증가하여 2025년에 는 $19 \%$ 를 점유할 것이라는 주장을 하고 있다. 우리나라 에서 '노인 병원' 의 설립 때 관련되는 법령은 일반병원 설립 때 적용되는 의료 관련 법령과 건축 및 환경 관련 법령 외에도 현재 노인복지법이 적용되고 있으며 입법 절차가 이뤄지고 있는 법령으로 노인수발보장법, 고령 화시대 대책기본법 및 고령친화산업지원법 등 어떤 형 태의 조정과 지원이 보장될 지 가늠하기 어려운 상황이 다. 노인병원계는 한정된 국민복지 재정과 의료비로써 양적 질적 요구가 팽대하는 노인 의료의 부담이 정부에 서 의료계로 전가될 가능성이 있다는 일말의 불안을 지
울 수가 없다는 사실이다.

그렇다면 노인의 복지 문제 중 가장 심각하면서도 기 본적인 보건의료는 어디까지 왔는가?

우선 몇 개국의 노인 의료체계와 그 정책을 살펴보면, 미국은 일반 인구 계층과 차이 없이 메디케어 보험제도 가 그 주축이나 재원은 다변화되어 있고 저소득 노인 보 험료는 경감을 하고 있다. 일본의 노인 보건의료제도는 1960년대 이후 여러 차례 변화를 거듭하여 1982년 노 인보건법이 제정되어 노인 보건의료를 뒷받침함으로써 이제는 예방 차원의 노인의료가 적용되고 있다. 즉, 일 본은 전 국민 의료보험제도가 있음에도 불구하고 노인 만을 위한 별도의 의료비 지불 제도를 도입한 것으로, 이는 급속한 인구 고령화에 대한 대비책을 세우고 있음 을 시사한다. 또한 유럽 선진 각국의 노인 보건의료는 별도 체계가 없이도 포괄적인 일반 의료제도로 충분히 감당하고 있다.

우리나라의 노인 인구비나 절대 노인 인구수가 최근 폭증함에도 불구하고 노인 보건의료와 의료기관의 관리 는 종합적인 구도 하에서 이뤄진다기 보다는 부분적으 로 그 수요의 증가에 따른 무계획적인 시장원리에 맡겨 져 있으므로 국민복지 차원으로 노인 문제에 접근하고 있다고는 여겨지지 않는다. 최근 우후죽순격인 노인(요 양)병원의 급증 현황을 파악하고 향후 노인복지 차원의 노인 질환 관리를 어떻게 접근할 것이며 노인병원은 어 떻게 관리되고 운영되어야 하는지를 짚어보고자 한다.

\section{노인병원 현황}

의료법에 명시된 ‘요양병원' 은 의사 또는 한의사가 그 의료를 행하는 곳으로서 요양환자 30 인 이상을 수용 할 수 있는 시설을 갖추고 주로 30 일 이상 장기 요양을 
Table 1. Numbers of Geriatric Care Hospitals and Their Beds in 2006

\begin{tabular}{|c|c|c|c|c|c|c|c|c|c|}
\hline 지역|구분 & 서울 & 부산 & 대구 & 인천 & 광주 & 대전 & 울산 & 경기도 & 강원도 \\
\hline 병 원 & 12 & 22 & 13 & 7 & 4 & 3 & 11 & 16 & 3 \\
\hline 병 상 & 1,219 & 2,518 & 1,405 & 973 & 502 & 288 & 1,005 & 5,580 & 403 \\
\hline 지역|구분 & 충북 & 충남 & 전북 & 전남 & 경북 & 경남 & 제주도 & 합 & 계 \\
\hline 병 원 & 10 & 7 & 13 & 7 & 17 & 19 & 2 & \multicolumn{2}{|c|}{168} \\
\hline 병 상 & 1,541 & 4,117 & 1,095 & 930 & 2,085 & 2,562 & 149 & \multicolumn{2}{|c|}{26,540} \\
\hline
\end{tabular}

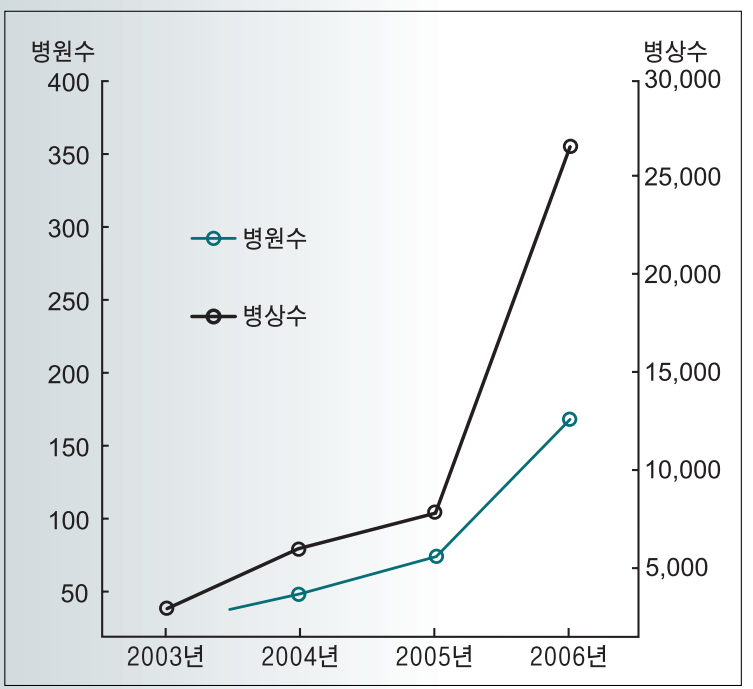

Figure 1. Increasing trends of geriatric care hospital from 2003 to 2006. Abrupt increasing rate is revealed during 1 year from 2005 to 2006. The statistics for geriatric care hospital was not done until 2001. (2002, 2003, 2004, 2005 \& 2006 Year Statistics Hospital in Korea, Korean Hospital Association)

요하는 입원환자에 대하여 의료를 행할 목적으로 개설 하는 의료기관으로 정의되어 있는데, 이러한 기준으로 따진다면 더 많을지 모르나, 대한병원협회가 발행한 2006 년 전국병원명부에 따르면, 전국에 168 개 요양병 원이 개설되어 있고 병상 수는 26,540 개이므로 전국 병 원 수 $(1,356)$ 의 $12 \%$ 와 전국 병상 수 $(267,815)$ 의 $10 \%$ 에 해당한다. 지역별로 보면, 요양병원 수는 22 개로 부
산이 가장 많으며 병상 수는 경기도가 5,580개로 가장 많다(Table 1). 전국 노인병원의 연간 추이를 보면, 2003년에 병원 수도 20 여개에 병상 수는 1,000 개 미만 이었으나 2006년에는 전년도에 비해서만도 병원 수와 병상 수가 각각 3 배 이상 증가하였다(Figure1).

\section{노인병원 현황}

수요의 증가가 공급을 부르는 것은 자본주의의 기본 적인 경제 원리이다. 노인 인구의 증가는 노인병원의 신 설 내지는 증설을 불러 일으켰다. 치매환자 요양병원을 제외하면 거의 민간 개설병원이다. 노인병원의 운영 형 태는 개인, 의료법인, 사회복지법인 및 시도립으로 구분 된다. 후자를 제외하면 전자 세 형태 모두 민간 운영으 로, 그 민간 운영의 노인병원이 136 개에 8,770 병상을 유지하고 있다.

지나치게 수익성에만 초점을 맞춰 의료에 대한 사회 투자가 잘못 이뤄지는 상황은 정부나 의료인 모두가 경 계해야 할 큰 문제로 대두되고 있다. 요양병원의 엄격한 진료 대상 질환은 대부분 만성 대사성 또는 퇴행성 질환 과 상해 또는 수술 후 장기 회복이며, 치매 등의 정신 질 환이나 전염성 질환은 제외된다. 대상 질환의 특성상 단 위 재원일 당 의료비는 낮을 수밖에 없고 물론 그 만큼 
의 의료 인력은 많이 요구되는 것은 아니지만 수익성을 크게 기대할 수 없음은 당연하다. 또한 국민의 복지문제 인 노인병 관리가 지나친 시장원리나 마케팅 차원에 내 맡겨지는 것은 국가나 노인병원 또는 주체인 국민에게 모두 부담스런 일을 자초할 것이다. 총체적 질 관리 차 원에서 비용과 질의 평형을 유지하고 질이 기대 만큼의 신장을 보일 때 불필요한 부분의 비용 절감은 가능할 것 이며 양자의 평형 확보까지는 정부가 책임질 수 밖에 없 다고 여겨진다. 의료기관도 수익성에만 급급하여 방향 을 잃고 전력 질주하면 결국 공멸하는 불운을 겪을 수도 있음을 인지해야 한다.

\section{국가 정책과 의료계의 대응}

노인 복지는 국가의 몫임을 누구도 부인하지는 못할 것이다. 복지 국가를 외친 지 오래이고 노인 문제의 양 적 증가와 그 심각성은 사회적 국가적인 문제로 대두된 지 오래이기 때문이다. 노인병원의 국가 차원의 지원은 6 개소 1,000 병상의 융자지원이 있었으나 그나마 1999 년 이후에는 중단된 상태다. 이렇게 중앙 정부의 노인의 료의 대처가 소극적이고 미만적인 상황에서, 지금은 시 도립 치매요양병원이 꾸준히 늘고 있는 것이 그나마 다 행인 셈이다.

노인병원의 의료비는 일반 병원과 차등화가 곧 이뤄 진다고 한다. 노인 병원 운영자의 입장에서는 일말의 불 안을 안고 있다. 현재 입원료는 일반 병원의 $80 \%$ 이고 6 개월 단위로 $5 \%$ 씩 차감되고 있으며 2005년부터 시작 된 시범 사업 결과에 따라 노인병원 건강보험 수가가 조 정될 전망이다. 노인병원은 빈번한 또는 고도의 시술을 하는 곳이 아니기 때문에 어떤 면에서는 입원료가 병원 운영비의 많은 부분을 책임져야 한다는 예상도 가능하
다. 게다가 개인이든 법인이든 무조건적인 재정 지원처 가 없고, 수익 창출에 의한 경영이라면 정부 정책에 대 한 정보와 경영 전략은 물론 타 기관보다 질적 우위를 점해야 하는 경쟁은 불가피하다. 또한 노인 인구비나 노 인환자가 대폭 증가한 것이지 전체 인구나 환자가 늘어 난 것은 아니기 때문에 부분적으로는 기존 일반 병원의 병상이 노인병원으로 이동되는 현상으로 볼 수도 있다. 따라서 노인병원 대상 환자가 증가한 만큼 병상 증가가 요구된다고 보기는 힘들다. 모든 일선 의료기관 입장에 서 보면, 경쟁력 확보를 위한 차원에서 지역 내 집중화, 세부시장 점유, 또는 서비스 차별화 등 여느 병원 관리 와 다를 바 없다. 노인병원이기에 이미 보장된 부분이 있을 거라는 막연한 기대는 허용되지 않으며 오히려 불 리한 조건만 가진 셈이다.

\section{바람직한 노인의료 운영 방향}

민간 주도냐, 정부 주도냐가 문제가 아니라 얼마나 실 효성있게 적정 의료비로 노인 의료 문제를 해결하느냐 하는 데에 초점을 맞춰야 할 것이다. 노인병원의 수요를 새로운 문제로, 또는 새로운 정책으로 맞설 것이 아니라 국민 보건 의료의 한 문제로 인식하고 현 상황에 대한 파 악과 분석으로 의료 시설을 지원하고 향후 예측된 정도 의 신장을 유도함으로써 적정 의료비로 국가적 복지도 확보하면서 기존 노인 의료 시설의 도산 등 충격에 의한 사회적 불안도 방지할 수 있을 것이다. 노인 의료 수요의 증가가 절대 수가 증가한 부분도 있지만 인구 비의 불균 형에 의한 부분이 많으므로 실제 노인 병원 병상 수는 기 존의 일반 병상 수의 일부가 전환되는 결과로 볼 수 있 다. 즉, 정부는 노인의료의 수요를 정확히 분석하여 병상 증설의 지도를 통해 공급의 적정성을 확보해야 한다. 
이미 민간 요양병원이 수요의 대부분을 충족시킬 만 큼의 양적 팽창이 이뤄진 상태라면 국가적 차원에서는 규제가 아닌 지원이라는 틀에서 정리가 이뤄져야 한다. 정부 수준의 투자가 독립적으로 이뤼지거나 협조체제가 이뤄지지 않으면 민간투자 병원의 도산은 명약관화한 일이고 국가적 손실은 당연히 감수하여야 할 것이다. 지 금 이 시점에서의 바람직한 노인병원 수요 대책은 새로 운 계획이나 정책으로 가시적 정치 문제로 접근하는 것 은 위험한 일이므로 기존 노인 병원의 수급을 파악하여 이를 지원하며 사명감과 의욕을 북돋우는 쪽에서 접근 해야 된다고 사료된다. 이에 따른 중요한 실질적 문제는 노인 의료비의 재원 충당을 어떻게 하느냐하는 것이다. 보험재정의 부담도 해결해야 할 문제이고 노인소득 불
균형으로 인한 양질의 서비스에 대한 소외계층을 줄이 는 것도 문제이다.

결론적으로, 노인병원은 양적 팽창, 수요의 적정성만 으로 평가되어서는 안되고 꾸준한 의료 질적 향상을 도 모하여 국민/노인 복지의 궁극적인 목표인 환자의 삶의 질을 높이기 위한 모든 노력을 지속적으로 기울여야 할 것이다. 정부 단독이나 어느 특정 계층 혹은 하나의 전 문 분야에서 해결될 수 없는 어려운 문제로 여겨지지만 노인 의료서비스에 대한 정부 차원의 법적, 제도적 및 재정적 지원 등의 많은 연구와 사회 각 분야의 국민복지 로서의 공감대가 요구될 뿐 아니라 노인병원에 적합한 관리체계와 의료 질적 향상을 위한 노인병원 자체의 노 력도 절실히 요구된다. 이 